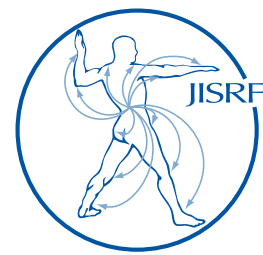

\title{
Trunnion Corrosion and Early Failure in Monolithic Metal-on-Polyethylene TMZF Femoral Components: A Case Series
}

Walker $P^{1}$, Campbell $D^{2}$, Della Torre $P^{1}$, Brazil $D^{3}$, McTighe $T^{4}$

\begin{abstract}
We describe four patients who were treated with primary total hip arthroplasty (THA) at two tertiary academic Australian teaching hospitals that experienced premature failure of head-neck trunnions through dissociation of the head-neck taper junction. This retrospective case series has similar clinical presentations and macroscopic pathology with severe head-neck taper junction loss of material, corrosion and early catastrophic failure. It is proposed that the accelerated wear is related to use of varus offset neck in a proprietary beta titanium alloy (Ti-12Mo-6Zr-2Fe or TMZF $^{\circledR}$ Stryker Osteonics, Mahwah NJ, USA) TMZF femoral stem, longer head-neck combination in a relatively active, older, male patient population. In this limited case series presentation was on average 80 months (range 53-92) following index procedure. In three of the four patients, a prodromal period of groin or buttock pain was reported for between 1 week and 2 months prior to acute presentation. Significant metallosis and local tissue damage including gluteal muscle insufficiency was evident. Each stem revised was well fixed. An extended trochanteric osteotomy was required in two of the four cases for stem extraction. We recommend caution and further evaluation on the relationship between TMZF metal alloy and its longevity in higher demand patients with high neck offset, varus stem geometry and large $\mathrm{CoCr}$ bearing heads.
\end{abstract}

Keywords: hip, arthroplasty, taper, metallurgy, titanium alloy, corrosion, trunnion, revision Level of Evidence: AAOS Therapeutic Level IV

1. Peter Walker, MD; Dr Paul Della Torre; Concord Repatriation General Hospital, Hospital Rd, Concord NSW 2139 AU

2. David Campbell, MD; Wakefield Orthopaedic Clinic, 270 Wakefield Street, Adelaide SA $5000 \mathrm{AU}$

3. Declan Brazil, PhD; Signature Orthopaedics, 7 Sirius Rd Lane Cove West NSW $2066 \mathrm{AU}$

4. Timothy McTighe, Dr HS (hc); Joint Implant Surgery \& Research Foundation, 46 Chagrin Shopping Plaza, \#117, Chagrin Falls, OH 44022 US

(Direct reprint requests to Paul Della Torre)
(C) 2016 Walker, Campbell, Della Torre, Brazil, McTighe. All rights reserved. Reconstructive Review is a peer-reviewed, open-access orthopaedic journal devoted to publishing papers in the area of reconstructive OPEN 2 ACCEsS arthroplasty. Authors retain copyright and grant the journal right of first publication with the work. Reconstructive Review follows the Creative Commons Attribution-NonCommercial CC BY-NC. This license allows anyone to download works, build upon the material, and share them with others for non-commercial purposes as long as they credit the senior author, Reconstructive Review, and the Joint Implant Surgery \& Research Foundation (JISRF). 


\section{Introduction}

Modularity in total hip arthroplasty (THA) design was introduced more than 30 years ago [1,2]. Potential benefits included a greater intraoperative flexibility to adjust leg length, offset and stability, ease of component revision and decreasing overall prosthetic inventory. Modular head-neck tapers vary in their geometry, size, conical angle, finish and metallurgy. An extensive number of tapers are available across the many device manufacturers (Image 1) [3]. The effect of taper length and diameter on the potential for corrosion is controversial. A shorter trunnion length reduces the available taper surface area for interference fit and therefore may predispose to micro motion whereas a longer trunnion with wider taper angle may contribute to mechanically assisted crevice corrosion (MACC) $[4,5]$.
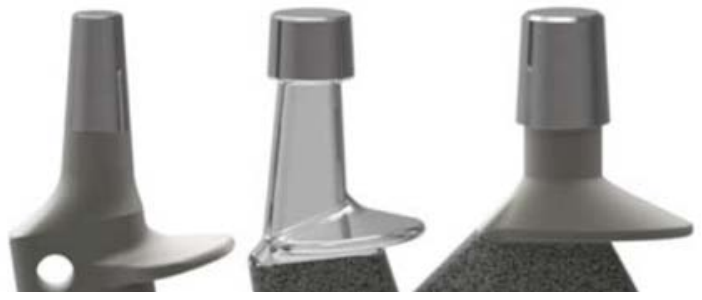

Image 1: Illustration Showing Different Taper Designs by Manufactures. (Courtesy of Chris Burgess, Signature Orthopaedics Ltd.)

Retrieved uncemented titanium alloy femoral stems with a modular cobalt-chromium $(\mathrm{CoCr})$ head have been associated with crevice corrosion at the taper interface [6,7]. Dissimilar metals have a greater propensity for galvanic corrosion however studies have shown same metal alloys are also susceptible to taper corrosion. This supports the most likely mechanism behind corrosion at the headneck interface being MACC rather than galvanism [8-10]. In certain combinations of high offset titanium alloy stem, with large $\mathrm{CoCr}$ heads, fretting and micro motion at the head-taper junction may result in additional factors leading to early implant failure (Image 2).

A proprietary beta titanium alloy (Ti-12Mo-6Zr-2Fe or TMZF $^{\circledR}$ Stryker Osteonics, Mahwah NJ, USA) was marketed as have greater tensile strength and flexibility than standard Ti-6Al-4V alloys to more closely mimic the modulus of elasticity of cortical bone [11]. TMZF was thought to also have a greater fatigue strength, improved wear and abrasion resistance. Two TMZF femoral stems have since been recalled in the United States by the Food and Drug Administration (FDA) - Rejuvenate ${ }^{\circledR}$ modular and ABGII ${ }^{\circledR}$ modular (Stryker Osteonics, Mahwah NJ, USA) after post-market data showed signs of Adverse Local Tissue Reaction (ALTR) due to fretting and corrosion at the modular neck junction [12]. The Accolade ${ }^{\circledR}$ (Stryker Osteonics, Mahwah NJ, USA) femoral stem was also manufactured

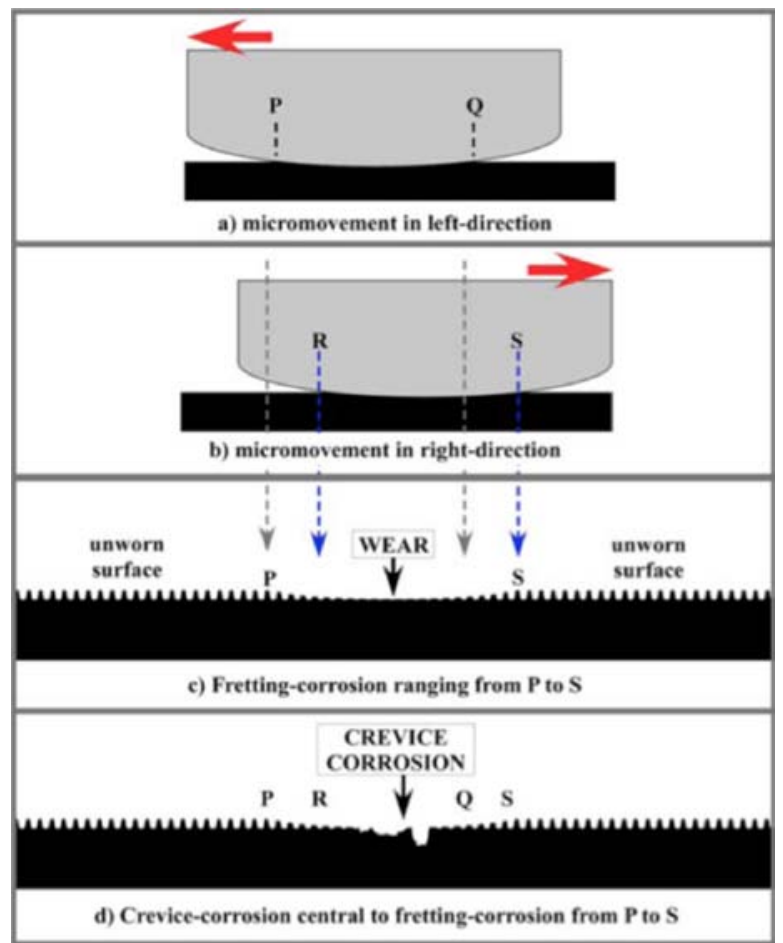

Image 2: Schematic illustrating that oscillatory motions as small as 10-100u can induce wear and mechanically-assisted crevice corrosion (MACC). Such relative motion is unavoidable because modular junctions inherently introduce parts of different rigidity (size, shape) and different alloys (stiffness criteria). (Courtesy of Ian Clarke \& Timothy McTighe)

from TMZF titanium alloy. Through a series of design changes, the Accolade $\mathrm{II}^{\circledR}$ (Stryker Osteonics, Mahwah NJ, USA) has replaced the Accolade ${ }^{\circledR}$ stem and is not manufactured from TMZF ${ }^{\circledR}$. The Accolade ${ }^{\circledR}$ TMZF $^{\circledR}$ was one of the top ten uncemented femoral stems implanted for primary THR in Australia up until 2013, where it subsequently was replaced in the 2014 data by the Accolade II [13].

The aim of this study is to report the experience of two tertiary academic Australian teaching hospitals with premature failure of four CoCr - Accolade ${ }^{\circledR}$ TMZF $^{\circledR}$ THAs through dissociation of the head-neck taper junction.

\section{Materials and Methods}

This retrospective case series of four patients have similar clinical presentations and macroscopic pathology with severe head-neck taper junction corrosion and early catastrophic failure. It is proposed that the accelerated wear is related to use of varus offset neck in TMZF femoral stem, longer head-neck combination in relatively active, older male patients.

The demographics of the four patients are detailed in Table 1.

Routine diagnostic cobalt and chromium metal ions 
Table 1: Patient Demographics and Characteristics (NIDDM - Non insulin Dependent Diabetes Mellitus, CCF - Congestive Cardiac Failure, $A F-$ Atrial Fibrillation)

\begin{tabular}{|c|c|c|c|c|c|c|c|c|c|}
\hline & \multicolumn{9}{|c|}{ Patient Characteristics } \\
\hline Patient & $\begin{array}{c}\text { Age at Primary } \\
\text { THA (yrs) }\end{array}$ & Sex & Presentation & $\begin{array}{l}\text { BMI } \\
(\mathbf{k g} / \\
\left.\mathbf{m}^{2}\right)\end{array}$ & Comorbidities & $\begin{array}{c}\text { Age at } \\
\text { Revision } \\
\text { THA } \\
\text { (yrs) }\end{array}$ & $\begin{array}{c}\text { Duration } \\
\text { of THA } \\
\text { Implantation } \\
\text { (months) }\end{array}$ & $\begin{array}{l}\text { Activity } \\
\text { Level }\end{array}$ & $\begin{array}{l}\text { Time } \\
\text { to Pain }\end{array}$ \\
\hline 1 & 68 & M & $\begin{array}{l}\text { Ache and } \\
\text { buttock } \\
\text { stiffness for } \\
\text { over } 1 \text { month. } \\
\text { Spontaneous } \\
\text { dissociation }\end{array}$ & 30 & $\begin{array}{c}\text { Ex smoker, } \\
\text { laryngeal } \\
\text { cancer }\end{array}$ & 76 & 89 & $\begin{array}{c}\text { Very } \\
\text { active, } \\
\text { walking, } \\
\text { gym } \\
\text { instructor }\end{array}$ & $\begin{array}{c}1-2 \\
\text { months }\end{array}$ \\
\hline 2 & 64 & M & $\begin{array}{l}\text { Sudden onset } \\
\text { buttock pain, } \\
\text { with limp }\end{array}$ & 26 & $\begin{array}{l}\text { Hypertension, } \\
\text { controlled } \\
\text { NIDDM }\end{array}$ & 72 & 92 & $\begin{array}{c}\text { Very } \\
\text { active, } \\
\text { golf, light } \\
\text { sport }\end{array}$ & $\begin{array}{c}<1 \\
\text { week }\end{array}$ \\
\hline 3 & 65 & M & $\begin{array}{l}1 \text { month groin } \\
\text { pain, } 1 \text { week } \\
\text { clicking with } \\
\text { instability and } \\
\text { several falls }\end{array}$ & 31 & $\begin{array}{l}\text { Hypertension, } \\
\text { controlled } \\
\text { NIDDM }\end{array}$ & 72 & 53 & $\begin{array}{l}\text { Moderately } \\
\text { active, golf } \\
\text { weekly }\end{array}$ & $\begin{array}{c}1 \\
\text { month }\end{array}$ \\
\hline 4 & 72 & M & $\begin{array}{c}\text { Acute } \\
\text { dissociation, } \\
\text { unprovoked }\end{array}$ & - & $\begin{array}{l}\text { CCF, AF, Vit } \\
\text { B12 deficiency, } \\
\text { prostate cancer }\end{array}$ & 80 & 84 & $\begin{array}{l}\text { Sedentary, } \\
\text { no sport }\end{array}$ & $\begin{array}{c}<1 \\
\text { week }\end{array}$ \\
\hline
\end{tabular}

were not performed in any patient due to the mechanical nature of each presentation and the obvious need for acute revision. No patient presented with a clinical suspicion of sepsis. Routine blood tests were performed for each patient, with a normal CRP $(3.0 \mathrm{mg} / \mathrm{L}$, normal $<5 \mathrm{mg} / \mathrm{L})$ recorded in Patient 1.

Patient 1 was an active obese 76 year old male with a primary right THA implanted without complication over 7 years prior. He complained at presentation of 1-2 months of insidious right buttock pain which was activity related. The patient noted a sudden pain in the right groin and a leg length discrepancy while sitting on a chair. Acute radiographs in the emergency department showed an acute dissociation at the head-taper junction (Image 3).
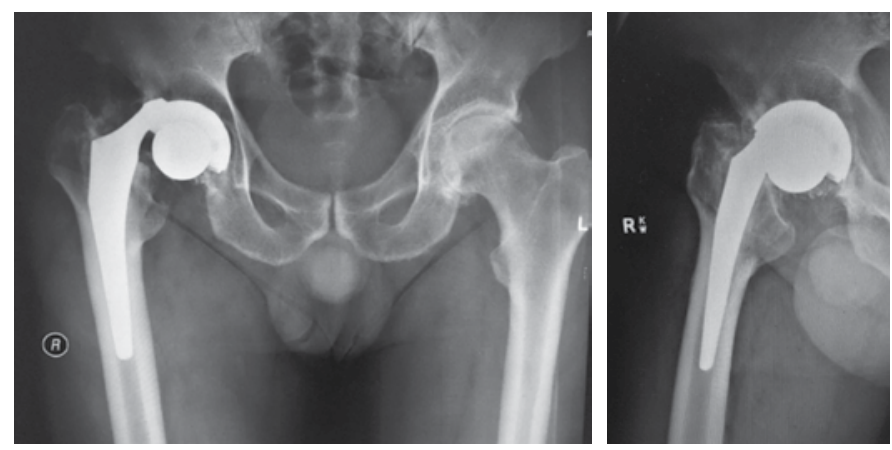

Image $3 a$ and $3 b$ : Patient 1 presenting anteroposterior and lateral radiographs dissociated head/neck taper junction of right total hip replacement.
Patient 1 underwent femoral stem revision through a standard posterior approach with flexible osteotomes. Significant metallosis was debrided (Image 4), and a modular distally fixed stem was implanted. Acetabular liner and head components were also replaced. The original acetabular shell was not affected and thus retained.

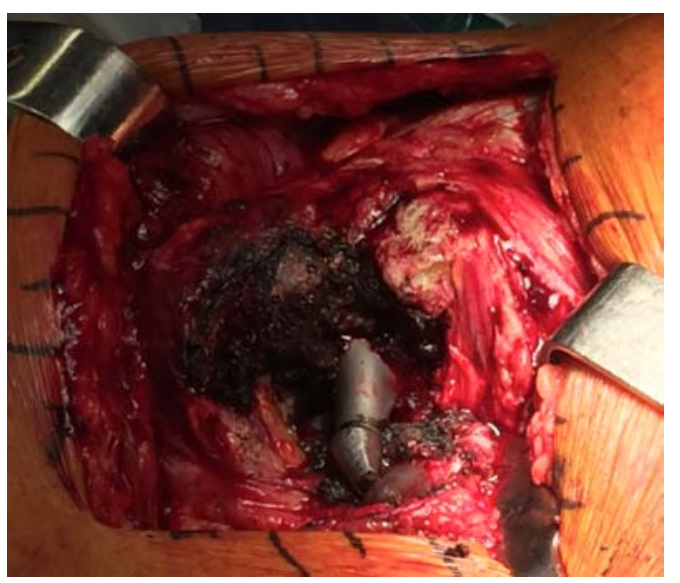

Image 4: Patient 1: Macroscopic appearance at revision of significant metallosis, dissociated neck taper junction, severe taper corrosion and gluteal muscle insufficiency.

The retrieved femoral stem in Patient 1 showed severe taper corrosion as the cause of the spontaneous dissociation (Image 5). Histopathology confirmed significant metallosis with no sign of active or chronic inflammation.

Patient 2 was an active mildly overweight 72 year old male who played golf and light sport. He underwent a routine right THA 7.5 years prior for osteoarthritis. On presen- 


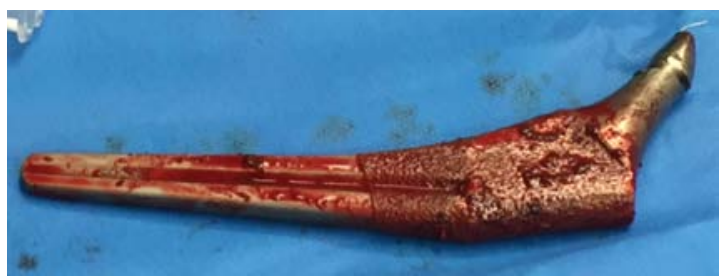

Image 5: Patient 1: Retrieved femoral stem showing marked corrosion of the neck taper.

tation Patient 2 described an episode of spontaneous right buttock pain with a limp. Radiography of the right hip prior to the revision showed catastrophic failure of the trunnion with varus malalignment at the head-neck junction (Image 6).

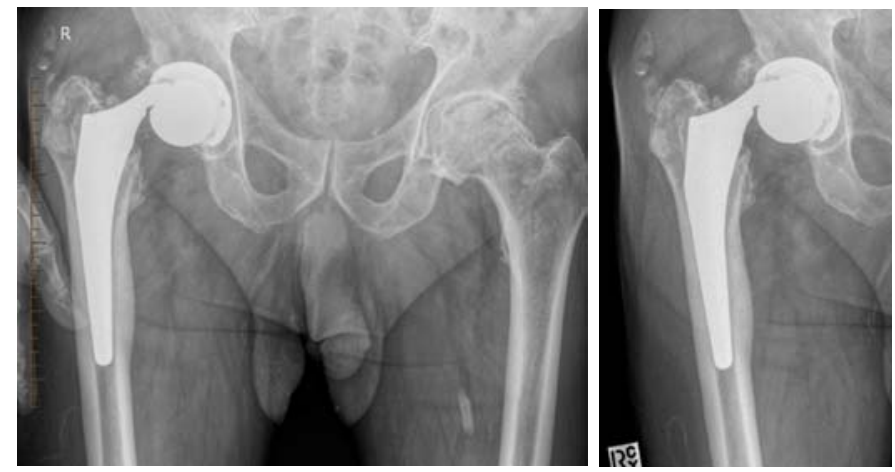

Image $6 a$ and 6b: Patient 2: Presenting anteroposterior radiographs showing prosthetic head/neck dissociation

Patient 2 underwent a revision THA with extended trochanteric osteotomy through a posterior approach. Metallosis surrounding the implant and gluteal muscles was debrided (Image 7) and components exchanged. Histopathology showed a moderate degree of chronic inflammation prosthesis detritus.

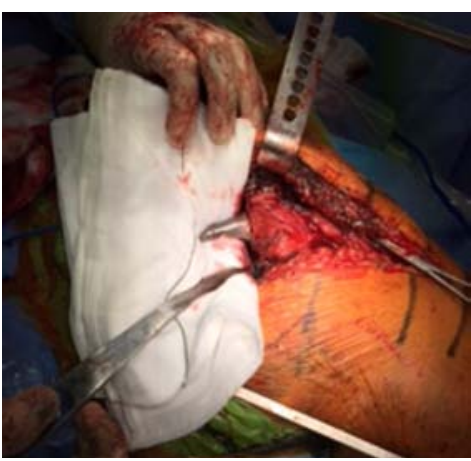

Image 7: Patient 2: Revision THA with metallosis, and significant neck taper corrosion.
The retrieved femoral stem from Patient 2 revealed significant taper corrosion and instability of the head-neck junction with inferior notching of the neck from instability (Image 8). A modular distally fixed stem was successfully

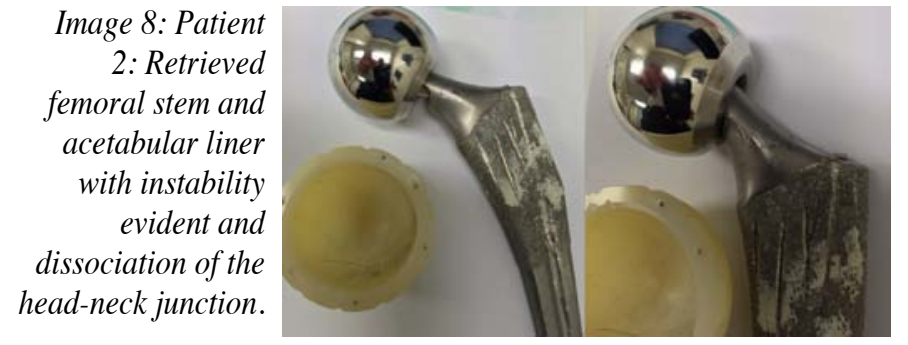

implanted with a $32 \mathrm{~mm}$ head.

Patient 3 was a moderately active obese man who played golf weekly and had an uncomplicated primary left THA performed 4 years prior to presentation. Over one month he developed groin pain with symptoms worsening to a clicking feeling and sensation of instability. Patient 3 sustained a number of falls prior to revision of the left THA. Radiographs of the left THA revealed a varus dissociation of the neck taper junction (Image 9).

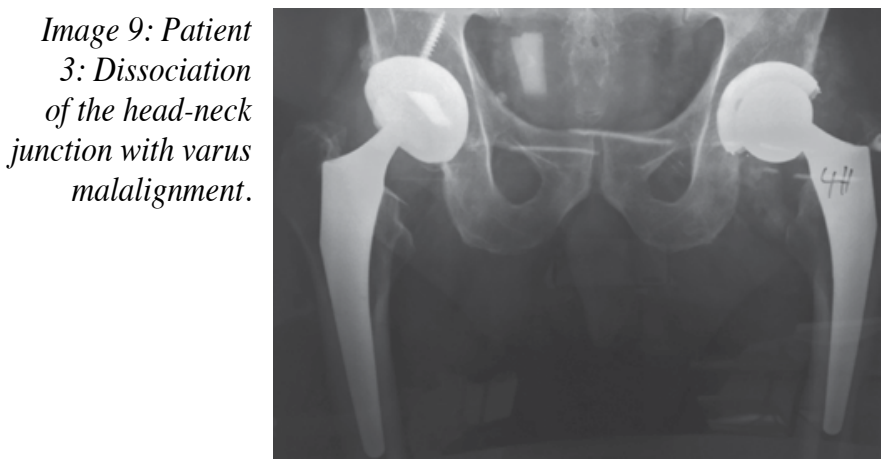

Patient 3 successfully underwent revision left THA through a posterior approach with an extended trochanteric osteotomy required for stem extraction. Significant metallosis was debrided at the time of

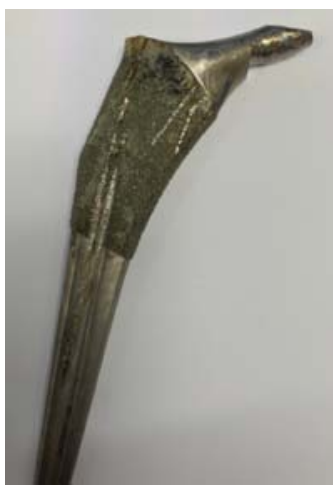

Image 10: Patient 3: Retrieved femoral stem with marked neck taper corrosion and inferior notching.

surgery throughout the periarticular tissues. The retrieved femoral stem showed significant taper corrosion with notching of the inferior neck due to instability (Image 10).

Patient 4 was a sedentary 80 year old man with multiple medical comorbidities. $\mathrm{He}$ underwent an uncomplicated primary right THA 7 years prior and presented with a sudden episode of

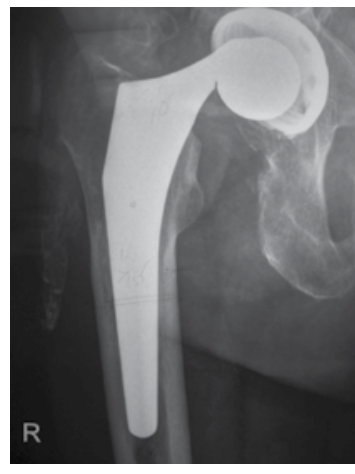
Image 11: Patient 4: Presenting anteroposterior radiograph of the dissociated head-neck junction of the right THA. unprovoked dislocation. Radiographs at presentation revealed a head-neck dissociation with abnormal wear evident on the taper (Image 11).

At revision of the right THA, metallosis was debrided and an isolated stem revision was successfully performed with a distally fixed prosthesis and exchange of the 
modular primary components. The retrieved femoral stem prosthesis had marked corrosion of the taper with inferior notching (Image 12).

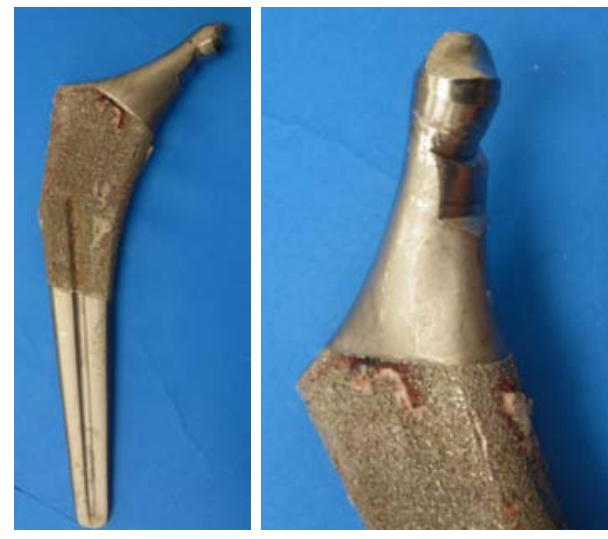

Image $12 a$ and 12b: Patient 4: Retrieved femoral stem prosthesis with taper corrosion evident and inferior neck notching.

\section{Results}

\section{Clinical presentation:}

In this limited case series of four failed primary THA patients, presentation was on average 80 months (range 53-92) following index procedure. In three of the four patients, a prodromal period of groin or buttock pain was reported for between 1 week and 2 months prior to acute presentation.

\section{Primary THA Implants:}

Each of the four patients had lateralised offset Accolade $^{\circledR} \mathrm{TMZF}^{\circledast}$ Plus stems implanted with lateralised offset $\mathrm{CoCr}$ heads of between $+4 \mathrm{~mm}$ and $+10 \mathrm{~mm}$. Index components are summarised in Table 2.

\section{Radiographic findings:}

Two of the four patients presented with complete headneck taper dissociation. The other two presented with impending dissociation, and instability at the damaged taper. Subtle osteolysis was evident in zone 7 of the medial femoral calcar in each case. Advanced imaging or specific laboratory cobalt and chromium ion analysis were not required due to the acute mechanical presentation and need for urgent revision in each case.

\section{Histopathology:}

Tissue pathology was performed in three of the four patients which showed an absence of acute inflammation, varying degrees of chronic inflammation and metal debris.

\section{Intraoperative findings:}

Significant metallosis and local tissue damage including gluteal muscle insufficiency was evident. Each stem revised was well fixed. An extended trochanteric osteotomy was required in two of the four cases for stem extraction.

\section{Post-operative Analysis:}

Metallurgical analysis in particular the marked corrosive changes seen macroscopically on the trunnion of each case is pending and will form the basis of a subsequent paper.

\section{Discussion}

There are several factors that can influence the rate at which corrosion develops at the head-neck taper junction. Metallurgy, implant geometry, bearing couple, implant assembly technique and specific patient factors can all influence the longevity of a THA.

Corrosion at the trunnion interface with dissimilar metals can be a cause of early failure in THA [14]. A modular head on a femoral stem is standard practice in modern THA to provide versatility in definitive implanting, ease component revision and to reduce the prosthetic inventory. A MoP bearing combination utilising a $\mathrm{CoCr}$ alloy metal head on a monolithic titanium alloy remains the most common bearing couple in modern THA.

Bearing surfaces also appear to contribute to corrosion with a greater propensity to corrosion found with metal on metal (MoM) than MoP bearing surfaces. Larger femoral head size, dissimilar alloy pairing at the trunnion interface, a varus femoral stem with lateralised offset head have been associated with greater taper corrosion in metal on metal MoM bearing couples $[15,16]$. Corrosion appears to be more prominent with longer implantation time and with MoM than MoP bearing surfaces. A hard on soft bearing couple such as a ceramic femoral head (with or without an articulating same metal sleeve) on a polyethylene liner may reduce taper corrosion and fretting $[15,17]$.

Techniques of trunnion cleaning during component assembly and femoral head impaction technique may influence head-neck stability. There is a direct linear relationship between impaction force and the force needed for disassembly [16]. Impacting the head-neck components in a dry, clean environment would seem ideal for component assembly [19]. A single impaction force of at least $4 \mathrm{kN}$ has been shown to achieve adequate head-taper junction strength in all bearing conditions [20].

Patient factors may contribute to the incidence of MACC by elevated BMI and greater activity level increasing the mechanical stress on the trunnion [14]. This limited case series that show similar macroscopic failure of the trunnion whist not proving causation, highlights the potential for accelerated MACC corrosion and early THA failure in a particular subset of patients. These are active, elderly and overweight males with a combination of a varus neck 
Table 2: Implant Details and outcomes of component revision.

\begin{tabular}{|c|c|c|c|c|c|c|c|c|c|}
\hline \multirow[b]{2}{*}{ Patient } & \multicolumn{5}{|c|}{ Femoral Component } & \multicolumn{2}{|c|}{ Acetabular Component } & \multicolumn{2}{|c|}{ Outcome } \\
\hline & $\begin{array}{c}\text { Femoral } \\
\text { Component }\end{array}$ & $\begin{array}{c}\text { Stem } \\
\text { Size }\end{array}$ & $\begin{array}{l}\text { Head } \\
\text { Offset } \\
(\mathrm{mm})\end{array}$ & Taper & $\begin{array}{c}\text { Head } \\
\text { Outer } \\
\text { Diameter } \\
(\mathbf{m m})\end{array}$ & $\begin{array}{l}\text { Acetabular } \\
\text { Size }(\mathbf{m m})\end{array}$ & Liner & $\begin{array}{l}\text { Histopathology } \\
\text { at Explantation }\end{array}$ & $\begin{array}{c}\text { Revision } \\
\text { Details }\end{array}$ \\
\hline 1 & $\begin{array}{l}\text { Accolade } \\
\text { TMZF Plus } \\
\text { Hip Stem }\end{array}$ & $\begin{array}{c}4 \\
\text { high }\end{array}$ & +10 & V40 & 36 & 58 & $\begin{array}{c}\text { Trident } \\
\text { X3 } 0^{\circ} \\
\text { Polyethylene }\end{array}$ & $\begin{array}{l}\text { Metallosis, no } \\
\text { inflammation }\end{array}$ & $\begin{array}{l}\text { Stem } \\
\text { revision, } \\
\text { complete } \\
\text { resolution }\end{array}$ \\
\hline 2 & $\begin{array}{l}\text { Accolade } \\
\text { TMZF Plus } \\
\text { Hip Stem }\end{array}$ & $\begin{array}{c}4 \\
\text { high }\end{array}$ & +4 & V40 & 40 & 56 & $\begin{array}{c}\text { Trident } \\
\text { X3 } 0^{\circ} \\
\text { Polyethylene }\end{array}$ & $\begin{array}{c}\text { Prosthesis } \\
\text { detritus, chronic } \\
\text { inflammation }\end{array}$ & $\begin{array}{c}\text { ETO } \\
\text { diaphyseal } \\
\text { stem, } \\
\text { 32mm head }\end{array}$ \\
\hline 3 & $\begin{array}{l}\text { Accolade } \\
\text { TMZF Plus } \\
\text { Hip Stem }\end{array}$ & $\begin{array}{c}4 \\
\text { high }\end{array}$ & +4 & V40 & 40 & 56 & $\begin{array}{c}\text { Trident } \\
\text { X3 } 0^{\circ} \\
\text { Polyethylene }\end{array}$ & $\begin{array}{l}\text { We were not } \\
\text { able to locate } \\
\text { the histopath } \\
\text { report }\end{array}$ & $\begin{array}{c}\text { Stem } \\
\text { revision } \\
\text { with ETO, } \\
\text { complete } \\
\text { resolution }\end{array}$ \\
\hline 4 & $\begin{array}{l}\text { Accolade } \\
\text { TMZF Plus } \\
\text { Hip Stem }\end{array}$ & $\begin{array}{c}5 \\
\text { high }\end{array}$ & +5 & V40 & 36 & 58 & $\begin{array}{c}\text { Trident } \\
\text { X3 } 0^{\circ} \\
\text { Polyethylene }\end{array}$ & - & $\begin{array}{l}\text { Stem } \\
\text { revision, } \\
\text { complete } \\
\text { resolution }\end{array}$ \\
\hline
\end{tabular}

offset, lateralised large diameter $\mathrm{CoCr}$ head on the particular TMZF alloy found in Accolade ${ }^{\circledR}$ stem with a proprietary trunnion geometry $\left(\mathrm{V} 40^{\circledR}\right)$.

The time to failure in these four patients was 4.4 to 7.6 years. When implanting novel alloys and taper designs, the authors recommend yearly review after two years with a thorough clinical examination and surveillance plain radiography. Radiographs should be assessed for resorption of the medial calcar, evidence of osteolysis and changes in the surrounding pericapsular soft tissues of the hip. Early targeted investigations to further assess the symptomatic hip or concerns on plain radiographs may include full blood count with differential, C-reactive protein, erythrocyte sedimentation rate and serum cobalt and chromium levels. Advanced imaging studies may include ultrasound examination of the hip capsule and surrounding musculature, scintigraphy and metal artifact reduction magnetic resonance imaging sequences.

Further studies are needed to explore the relationship between the TMZF metal alloy and its mechanical longevity in higher demand patients with high neck offset, varus stem geometry and large $\mathrm{CoCr} \mathrm{MoP}$ bearing couple.

\section{Disclosure}

The authors declare that there is no conflict of interest regarding the publication of this paper. For full disclosures refer to last page of this journal.

\section{References}

1. HJ Cooper, CJ Della Valle, RA Berger et al. Corrosion at the Head-Neck Taper as a Cause for Adverse Local Tissue Reactions After Total Hip Arthroplasty. J Bone Joint Surg Am, 2012 Sep 19; 94 (18):1655-1661.

2. McTighe T, Brazil D, Clarke I, Keppler L, Keggi j, Tkach T, McPherson E. Metallic Modular Taper Junctions in Total Hip Arthroplasty.

3. Wassef AJ, Schmalzried TP. Femoral taperosis: an accident waiting to happen?. Bone Joint J. 2013 Nov;95-B(11 Suppl A):3-6

4. Langton DJ, Sidaginamale R, Lord JK, Nargol AVF, Joyce TJ. Taper junction failure in largediameter metal-on-metal bearings. Bone \& Joint Research. 2012;1(4):56-63.

5. Nassif NA, Nawabi DH, Stoner K, Elpers M, Wright T, Padgett DE. Taper Design Affects Failure of Large-head Metal-on-metal Total Hip Replacements. Clinical Orthopaedics and Related Research. 2014;472(2):564-571. doi:10.1007/s11999-013-3115-3.

6. Collier JP, Surprenant VA, Jensen RE, Mayor MB. Corrosion at the interface of cobalt-alloy heads on titanium-alloy stems. Clin Orthop Relat Res. 1991 Oct;(271):305-12.

7. Manthe M, Blasser K, Beauchamp C, O'Connor MI. Trunnion Corrosion Causing Failure in Metal-on-Polyethylene Total Hip Arthroplasty with Monolothic Femoral Components.

8. Goldberg JR, Gilbert JL, Jacobs JJ et al. A multicenter retrieval study of the taper interfaces of modular hip prostheses. Clin Orthop Relat Res. 2002 Aug;(401):149-61.

9. Gilbert JL, Buckley CA, Jacobs JJ. In vivo corrosion of modular hip prosthesis components in mixed and similar metal combinations. The effect of crevice, stress, motion, and alloy coupling. J Biomed Mater Res. 1993 Dec;27(12):1533-44.

10. Cook SD, Barrack RL, Clemow AJ. Corrosion and wear at the modular interface of uncemented femoral stems. J Bone Joint Surg Br. 1994 Jan;76(1):68-72.

11. Stryker Osteonics, TMZF Alloy: A Titanium Alloy Optimized for Orthoapaedic Implants. http://www.stryker.gr/st_pdf_ltmzfb.pdf (Accessed 10/8/2016).

12. Stryker Osteonics: Rejuvenate Modular / ABG II Modular-Neck Stem Voluntary Recall. http://www.stryker.com/en-us/products/Orthopaedics/modularneckstems/index.htm (Accessed 14/8/2016)

13. Australian Orthopaedic Association National Joint Replacement Registry, Annual Report 2015: Hip and Knee Arthroplasty. https://aoanjrr.sahmri.com/documents/10180/217745/Hip and Knee Arthroplasty. (Accessed 17/08/2016)

14. Jennings JM, Dennis DA, Yang CC. Corrosion of the Head-neck Junction After Total Hip Arthroplasty. J Am Acad Orthop Surg. 2016 Jun;24(6):349-56.

15. Munir S, Cross MB, Esposito $\mathrm{C}$ et al. Corrosion in modular total hip replacements: An analysis of the head-neck and stem-sleeve taper connections. Semin in Arthroplasty, Vol 24, Iss 4, 240-245.

16. Fricka KB, Ho H, Peace WJ, Engh CA Jr. Metal-on-metal local tissue reaction is associated with corrosion of the head taper junction. J Arthroplasty. 2012 Sep;27(8 Suppl):26-31.e1.

17. Huot Carlson JC, Van Citters DW, Currier JH et al. Femoral stem fracture and in vivo corrosion of retrieved modular femoral hips. J Arthroplasty. 2012 Aug;27(7):1389-1396.e1.

18. Pennock AT, Schmidt AH, Bourgeault CA. Morse-type tapers: factors that may influence taper strength during total hip arthroplasty. J Arthroplasty 2002 Sep;17(6):773-8

19. Donaldson FE, Coburn JC, Siegel KL. Total hip arthroplasty head-neck contact mechanics: a stochastic investigation of key parameters. J Biomech. 2014 May 7;47(7):1634-41.

20. Rehmer A, Bishop NE, Morlock MM. Influence of assembly procedure and material combination on the strength of the taper connection at the head-neck junction of modular hip endoprostheses. Clin Biomech (Bristol, Avon). 2012 Jan;27(1):77-83. 